\title{
Genetic Variation of Trees of Caryocar brasiliense for Fruit Morphometric Traits
}

\author{
Liliana Hernández Hernández ${ }^{1}$ \\ Fábio Araújo dos Santos ${ }^{2}$ (1) \\ Edwin Camacho Palomino ${ }^{3}$ \\ Evandro Vagner Tambarussi ${ }^{4}$ (10 \\ Cristiano Bueno Moraes ${ }^{1}$
}

\begin{abstract}
This study aimed to verify the genetic variability of matrix trees of Caryocar brasiliense, best known by the popular name of "pequi", in a completely random delineation, with 20 treatments (matrices), and 50 repetitions (collected fruits in each matrix). We have evaluated the following traits of each fruit: weight $(\mathrm{g})$, diameter $(\mathrm{cm})$, length $(\mathrm{cm})$, width $(\mathrm{cm})$, and thickness $(\mathrm{cm})$. As results we obtained a coefficient of experimental variation $\left(C V_{e}(\%)\right)$ that showed advantageous values of 2.82 to 7.80 , and the genotype heritability $\left(h_{g}^{2}(\%)\right)$ of 55 to 95 ; both results can indicate favorable genetic control in the traits of the fruit. At the same time certain traits have significant genotypic and phenotypic correlations, which can be understood as an advantage for the improvement of the specie. In conclusion, we have noted that the population of Caryocar brasiliense has a high genetic variation, these results support the planning for genetic improvement programs.
\end{abstract}

Keywords: pre-breeding, genetic variability, fruit, pequi, Cerrado.

Caryocar brasiliense Cambess, commonly known by the popular name of "pequi", is a typical native specie of the Brazilian Cerrado, it can be found in the states of Minas Gerais, Goiás, Mato Grosso, Tocantins, Bahía, Pará and Maranhão (Carvalho, 2009). It is an allogamous specie, with fruits rich in oils and vitamin A, which are very well appreciated by people and wild animals of the Brazilian cerrado (Collevati et al., 2001). Besides its importance, we still have little research on Caryocar brasiliense's genetic variability and its natural populations across the Cerrado, one reason for that may be the great extension of this biome (Moura et al., 2013).

Many different species of the Cerrado have been reported as of favorable genetic variability (Ganga et al., 2009; Carmargo et al., 2010), this information is a good indication to start breeding trials. Due to the lack of information on various aspects of Caryocar brasiliense, progeny tests, mainly used to estimate genetic parameters and select individuals, are an important tool (Aguiar et al., 2011) to calculate the genetic variability of the matrices, respecting the morphological traits of the fruits (Ramos et al., 2015).

Over the years the "Pequi" has shown great economic and social potentials, however, the agricultural expansion and the disorderly exploitation of timber resources has threatened the natural populations and communities that used to depend on it; because of that, the need to start genetic enhancement studies (Giordani et al., 2012) has become essential. Based on all these reasons, this research aimed to study the genetic parameters, and analyze the genetic variability of matrix trees of Caryocar brasiliense through the morphometric traits of its fruits.

The experiment was conducted at the Experimental Farm of the Federal University of Tocantins (UFT), campus of Gurupi, located under the coordinates $11^{\circ} 43^{\prime} 5 \mathrm{~S}$ and $49^{\circ} 04^{\prime} \mathrm{W}$, and at 280 meters above sea level. Accordingly to the Koppen's

${ }^{1}$ Universidade Federal do Tocantins, Calle Badejós, Palmas, TO, Brasil.

${ }^{2}$ Universidade Estadual Paulista Julio de Mesquita Filho, Botucatu, SP, Brasil.

${ }^{3}$ Universidade Federal do Oeste do Para, Santarem, PA, Brasil.

${ }^{4}$ Universidade Estadual do Centro-Oeste, Irati, PR, Brasil. 
classification, the climate in the region is Aw (tropical with dry season) and the soil is classified as a dystrophic RedYellow Oxisol (Embrapa 2018). We collected 50 fruits for each matrix tree of $C$. brasiliense, with a minimum distance of 50 meters between individuals to avoid kinship. For the study of the genetic variability, we used the following quantitative genetic parameters: fruit weight (FW (g)), width $(\mathrm{FW} 2(\mathrm{~cm}))$, thickness $(\mathrm{FT}(\mathrm{cm}))$, diameter $(\mathrm{FD}(\mathrm{cm}))$ and length $(\mathrm{FL}(\mathrm{cm}))$. The experiment was conducted in a specie's natural population, under a completely randomized design, with 20 treatments (matrix trees) and 50 fruits per tree.

The statistical significance was evaluated in accordance to the likelihood ratio test (LRT), the results were analyzed by the SELEGEN REML / BLUP (restricted maximum likelihood) a statistical-genetic software (Resende, 2007) used for completely random delineations, expressed in the mathematical equation: $y=X u+Z g+W p+e$, where, " $y$ " is the data vector, " $u$ " is the general average, "g" represents the genotypic effects of the matrices (assumed as random), "p" is the plot effects (random), "e" is for the vectors of the effects of random errors, and the uppercase letters represent the matrices of incidence.

The likelihood ratio test (LRT) showed significant variance at $5 \%$ in the characters of FW, FL, FT, FD and FW2, indicating genetic variability between the materials (individuals), which is favorable at the time of selection (Table 1).

Table 1. Likelihood ratio test (LRT) for traits of fruits of Caryocar brasiliense: weight (FW), width (FW2), thickness (FT), diameter (FD) and length (FL).

\begin{tabular}{llcccc}
\multirow{2}{*}{$\left(^{*}\right)$ LRT } & \multicolumn{5}{c}{ Features } \\
\cline { 2 - 2 }$(\mathbf{g})$ & FW2 $(\mathrm{cm})$ & FT $(\mathbf{c m})$ & FD $(\mathrm{cm})$ & FL $(\mathbf{c m})$ \\
\hline Fruit & $81.85^{*}$ & $94.23^{*}$ & $97.34^{*}$ & $5.72^{*}$ & $12.04^{*}$ \\
\hline $\begin{array}{l}\left(^{*}\right) \text { LRT fruit: Reason for likelihood in fruit characters; } \\
\text { of probability. }\end{array}$
\end{tabular}

The coefficient of experimental variation $\left(C V_{e}(\%)\right)$ has indicated that the adopted experimental design was adequate. The fruit had a weight of (7.8\%), which is in accordance to the values found in the literature (Moura et al., 2013). The Genotypic inheritance, in the broad sense, $\left(h_{g}^{2}(\%)\right)$ varied from $55 \%$ to $95 \%$, these results indicate high genetic control in the morphometric traits of the fruits (Table 2). The selective accuracy $\left(r_{\hat{a} a}\right)$ is an important parameter for maximizing genetic progress, for this trait the values were greater than 0.50, which corroborates with Resende (2007), that says that $r_{\hat{a} a}$ values greater than 0.50 , is ideal for a good accuracy in genotype selection. The value of the coefficient of individual additive genetic variation $\left(\mathrm{CV}_{g i}(\%)\right)$ varied from $2.90 \%$ to $6.12 \%$, and was low for the traits FW $(3.88 \%)$ and
FL (2.90\%), this can indicate that the studied individuals of Caryocar brasiliense have genetic variability available. The genetic gain $\left(G_{s}(\%)\right)$, was of $5.56 \%$ for FW, $12.20 \%$ for FW2, $14.33 \%$ for FT, $15.12 \%$ for FD and of $5.12 \%$ for FL. The fruit's thickness (FT) was the most outstanding value.

Table 2. Genotypic parameters for fruit weight (FW), width (FW2), thickness (FT), diameter (FD) and length (FL) of Caryocar brasiliense.

\begin{tabular}{|c|c|c|c|c|c|}
\hline \multirow{2}{*}{$\begin{array}{c}\text { Genetic } \\
\text { parameters }\end{array}$} & \multicolumn{5}{|c|}{ Features } \\
\hline & FW (g) & FW2 (cm) & FT $(\mathrm{cm})$ & FD $(\mathrm{cm})$ & FL $(\mathrm{cm})$ \\
\hline$h_{g}^{2}(\%)$ & 55 & 94 & 95 & 95 & 68 \\
\hline$r_{\hat{a} a}(\%)$ & 74 & 96 & 97 & 97 & 82 \\
\hline$C V_{g i}(\%)$ & 3.88 & 5.00 & 5.80 & 6.12 & 2.90 \\
\hline$G_{s}(\%)$ & 5.56 & 12.20 & 14.33 & 15.12 & 5.12 \\
\hline$C V_{e}(\%)$ & 7.80 & 2.82 & 2.89 & 3 & 4.50 \\
\hline Average & 15.38 & 2.88 & 2.69 & 2.51 & 3.83 \\
\hline
\end{tabular}

The correlations can guide the selection of a set of traits as a total, not for each character in isolation (Vencovsky \& Barriga, 1992). Our results showed a strong correlation between fruit weight $(r f \geq 0.72)$, and width $(r g \geq 0.94)$ (Table 3$)$. The correlations between the fruit's weight and its dimensional traits are interesting, specially because when selecting matrices that have fruits with larger transverse diameters, consequently it will be selected heavier fruits (more weight). The phenotypic correlations are useful in indirect selection, where gains can be made without restricting selection (Zobel \& Talbert, 1984). The significant unfavorable correlations were found between fruit weight $(r g \geq 0.87)$ and thickness $(r f \geq 0.60)$, because this implies a high proportion of fruit peel, which in small or medium productions would result in low yield.

Table 3. Phenotypic ( $r f)$ and Genotypic ( $r g$ ) correlations for fruit's characteristics in matrices of Caryocar brasiliense.

\begin{tabular}{lccccc}
${ }^{*}$ Characters & FW & FW2 & FT & FD & FL \\
FW & - & $0.723^{\star *}$ & $0.599^{\text {ns }}$ & $0.516^{\text {ns }}$ & $0.546^{\text {ns }}$ \\
FW2 & $0.948^{\star *}$ & - & $0.712^{\star}$ & $0.635^{\star}$ & $0.557^{\text {ns }}$ \\
FT & $0.877^{\star \star}$ & $0.952^{\star *}$ & - & $0.715^{\star}$ & $0.488^{\text {ns }}$ \\
FD & $0.454^{\text {ns }}$ & $0.613^{*}$ & $0.637^{\star}$ & - & $0.755^{\star}$ \\
FL & $0.392^{\text {ns }}$ & $0.407^{\text {ns }}$ & $0.324^{\text {ns }}$ & $0.699^{\star}$ & - \\
\hline
\end{tabular}

Phenotypic correlation $(r f)$ above the diagonal and genetic correlations $(r g)$ below the diagonal, for fruit weight (FW), width (FW2), thickness (FT), diameter (FD) and length (FL) of Caryocar brasiliense.

The integral maintenance of natural populations is important to preserve the viability of the species. The pairing system and the flow of the species' genes can be altered, resulting in a possible fragmentation of the natural populations of Caryocar brasiliense, which can decrease the population 
size (Collevati et al., 2001), reduce genetic variability, and increase endogamy (Tambarussi et al., 2017).

More researches aiming to study the genetic control of native species are necessary for the preservation and pre-improvement of the species (Faleiro et al., 2008). In conclusion, the trees of Caryocar brasiliense of the southern region of Tocantins has shown significant genetic variation; and high heritability according to the traits of its fruits, which has demonstrated more than sufficient potential to be explored in a genetic improvement program.

\section{SUBMISSION STATUS}

Received: 28 Feb. 2018

Accepted: 24 Sep. 2019

Associate editor: Natane Miranda

\section{CORRESPONDENCE TO}

\section{Liliana Hernández Hernández}

Universidade Federal do Tocantins, Calle Badejós, Lote 7, Chacras 69/72, Zona Rural Gurupi, 77001-090, Palmas, TO, Brasil e-mail: lilianah111@hotmail.com

\section{REFERENCES}

Aguiar AV, Moura NF, Moura MF, Zucchi MI, Venkovsky R, Chaves LJ. Relação entre a variação genética de caracteres quantitativos e marcadores moleculares em subpopulações de cagaiteira (Eugênia dysenterica DC). Revista Brasileira de Fruticultura, Jaboticabal, v. 33, n. 1, p. 157-169. 2011.

Camargo FF, Costa RB, Resende MDV, Roa RAR, Rodrigues NB, Santos LV, et al. Variabilidade genética para caracteres morfométricos de matrizes de castanha-do-brasil da Amazônia Mato-grossense. Acta Amazônica, Manaus, v. 40, n. 4, p 705-710, 2010.
Carvalho PER. Pequizeiro Caryocar brasiliense. Colombo- PR. Comunicado Técnico Embrapa 230. 2009. 10p.

Collevatti RG, Grattapaglia D, Hay JD. Population genetic structure of the endangered tropical tree species Caryocar brasiliense, based on variability at microsatellite loci. Molecular Ecology, v. 10, p. 349-356, 2001.

EMBRAPA. Sistema Brasileiro de Classificação de Solos. Embrapa Solos-Livro técnico (INFOTECA-E). Brasília, DF: 2018. 412p.

Faleiro FG, Neto ALF, Junior WQR. Pré-melhoramento, melhoramento e pós-melhoramento: estratégias e desafios. Brasília: Embrapa Cerrados, 2008. $184 \mathrm{p}$.

Ganga RMD, Chaves LC, Naves RV. Parâmetros genéticos em progênies de Hancornia speciosa Gomes do Cerrado. Scientia Forestalis, Piracicaba, v. 37, n. 84, p. 395-404, 2009.

Giordani SCO, Fernandes JSC, Titon M, Santana RC. Parâmetros genéticos para caracteres de crescimento em pequizeiro. Revista Ciência Agronômica, Fortaleza, v. 43, n. 2, p.146-153, 2012.

Moura NF, Chaves LJ, Naves RV, Aguiar AV, Sobieraki GR, Variabilidade entre procedências e progênies de pequizero (Caryocar brasiliense Camb.). Scientia Forestalis, v. 41, n. 97, p. 103-112, 2013.

Ramos BH, Coimbra RR, Chagas DB, Ferreira WM, Silva KLF. Variabilidade fenotípica de frutos de Caryocar brasiliense Cambess em três diferentes fitofisionomias do Cerrado. Revista Iheringia, Porto Alegre, v. 70, n. 1, p. 39-46, 2015.

Resende MDV. SELEGEN-REML/BLUP: Sistema estatístico e seleção genética computadorizada via modelos lineares mistos. Colombo: Embrapa Florestas, 2007. 359p.

Tambarussi EV, Boshier DH, Vencovsky R, Freitas MLM, Sebbenn AM. Inbreeding depression from selfing and mating between relatives in the Neotropical tree Cariniana legalis Mart. Kuntze. Conservation Genetics, v. 18, n. 1, p. 225-234, 2017.

Vencovsky R, Barriga P. Genética biométrica no fitomelhoramento. Ribeirão Preto: Sociedade Brasileira de Genética, 1992. 496p.

Zobel BJ, Talbert J. Applied forest: tree improvement. New York, John Wiley, 1984. 505p. 